\title{
Correction to: Arterial Wall Stiffening in Caveolin-1 Deficiency-Induced Pulmonary Artery Hypertension in Mice
}

\author{
J. Moreno ${ }^{1,2}$ - D. Escobedo ${ }^{3}$. C. Calhoun ${ }^{3}$. C.Jourdan Le Saux ${ }^{3,4}$ - H.C. Han ${ }^{1,2}$ \\ Published online: 23 November 2020 \\ (C) Society for Experimental Mechanics 2020
}

\section{Correction to: Experimental Mechanics. https://doi.org/10.1007/s11340-020-00666-6}

The original article was updated to include the missing section from eq. (4) to eq. (8). This error was introduced during production process and was not the fault of authors.

Publisher's Note Springer Nature remains neutral with regard to jurisdictional claims in published maps and institutional affiliations.

The online version of the original article can be found at https://doi.org/ 10.1007/s11340-020-00666-6

\footnotetext{
H. C. Han

hchan@utsa.edu

C. Jourdan Le Saux

Claude.LeSaux@ucsf.edu

1 Department of Mechanical Engineering, University of Texas at San Antonio, San Antonio, TX 78249, USA

2 Biomedical Engineering Program, UTSA-UTHSCSA, San Antonio, TX, USA

3 Department of Medicine/Cardiology, University of Texas Health Science Center At San Antonio, San Antonio, TX, USA

4 Department of Medicine/Pulmonary and Critical Care, University of California San Francisco, San Francisco, CA 94143, USA
} 